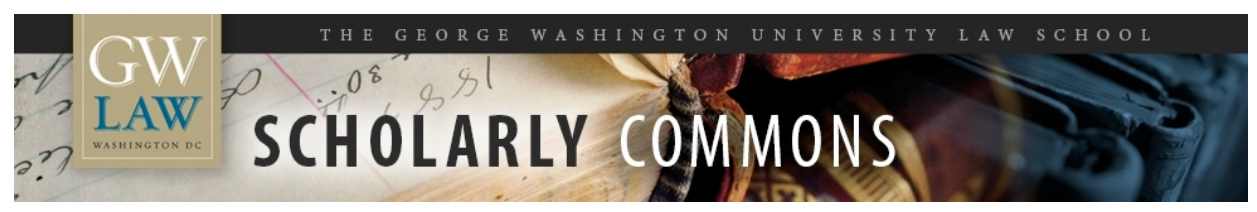

\title{
Desiderata: Objectives for a System of Government Contract Law
}

Steven L. Schooner

George Washington University Law School, sschooner@law.gwu.edu

Follow this and additional works at: https://scholarship.law.gwu.edu/faculty_publications

Part of the Government Contracts Commons

\section{Recommended Citation}

11 Public Procurement Law Review 103 (2002)

This Article is brought to you for free and open access by the Faculty Scholarship at Scholarly Commons. It has been accepted for inclusion in GW Law Faculty Publications \& Other Works by an authorized administrator of Scholarly Commons. For more information, please contact spagel@law.gwu.edu. 


\section{Desiderata: Objectives for a System of Government Contract Law}

\section{Professor Steven L. Schooner \\ George Washington University Law School \\ Washington, D.C.}

1. Introduction

Sometimes the most simple questions prove the most vexing. For example, what does your government hope to achieve through its government procurement law? It is possible to draft and enact a new law without answering the question, and experience demonstrates that this is often the case. (Arguably, it is equally challenging to sustain a commitment to these objectives over time, but that is a topic for another day.) Nonetheless, it seems reasonable to attempt to describe general aspirations for a procurement system before drafting begins.

Unfortunately, it is difficult to articulate objectives for a procurement system. ${ }^{1}$ There are many options, and most are contradictory. ${ }^{2}$ This paper will briefly address nine goals frequently

1 "The Federal Government has been making contracts for as long as it has existed, yet little attempt has been made to rationalize this phase of governmental activity in its relation to the functions of government and to the persons and firms with whom contracts are made." John Wm. Whelan \& Edwin C. Pearson, "Underlying Values in Government Contracts", 10 Pub. L. 298 (1962) ("suggest[ing] the need for such an explanation and rationalization"). Professor Whelan notes that: "Government contracts obviously fulfill one prime function: they are vehicles for the acquisition or disposal of property, performance of services or other such governmental ends may involve the use of promissory obligations." Ibid. at 302. He then catalogs four subsidiary functions: "(1) the expression of general public policy, (2) policies for the safeguard of government integrity, (3) imposition of government controls on contract performance and (4) reflections of certain intragovernmental relations." Ibid. at 303.

2 This reflects not only government procurement, but the nature of government. See Richard Stillman II, The American Bureaucracy: the Core of Modern Government 360-94 (2d ed., 1996), distinguishing the Hamiltonian, Jeffersonian, and Madisonian normative models and conceding that:

American have never made up their minds... as to which of the (continued...)

Publication pending at 11 Public Procurement Law Review 103 (2002) - Draft Page 1 
identified for government procurement systems: (1) competition; (2) integrity; (3) transparency; (4) efficiency; (5) customer satisfaction; (6) best value; (7) wealth distribution; (8) risk avoidance; and (9) uniformity. The author do not suggest this list is exhaustive, nor do the author expect that each individual label will resonate with all readers. Nonetheless, the list provides sufficient options to generate significant debate amongst scholars, policy makers, legislators, and, of course, buyers and sellers.

\section{Three Overarching Principles: Competition, Transparency, and Integrity}

At a macro level, the author prefers to begin with three "pillars" that, in my opinion, underlie the United States procurement system: system transparency; procurement integrity; and competition. ${ }^{3}$ In the United States, we believe that, as a general rule, our government enjoys access to the best contractors, lowest prices, most advanced technology, favourable contract terms and conditions, and the highest quality goods and services. We think this is so because our system, for the most part, encourages participation by the widest possible pools of potential competitors; it consistently demonstrates that competitors will be impartially considered for

\section{${ }^{2}(\ldots$ continued $)$}

three models they prefer... From time to time, the stress has been placed on promoting the values of administrative efficacy... at other times, accountability to the general public has predominated; and at still other times, responding to diverse interest group demands has clearly been an overriding priority. Yet, within any single historic period where one value has held sway over the other two, the others have never been entirely neglected or ignored.

Ibid. at 366 (emphasis added).

${ }^{3}$ To be clear, however, this perception is not universally accepted. Compelling arguments can be made for alternative desiderata.

Publication pending at 11 Public Procurement Law Review 103 (2002) - Draft Page 2 
award of our contracts; and it treats all contractors in a manner that balances appropriate risks with meaningful profit incentives and rewards. There are plentiful exceptions to this description, and a number are identified below.

We promote competition because we believe in the power of the marketplace. ${ }^{4}$ By maximizing the effective use of competition, the government receives its best value in terms of price, quality, and contract terms and conditions. ${ }^{5}$ Contractor motivation to excel is greatest when private companies, driven by a profit motive, compete head-to-head in seeking to obtain work. Yet, maintaining a robust competitive regime requires more than a commitment to the

${ }^{4}$ We believe the marketplace thrives because of human self-interest, which proves far more effective than legislated or regulated mandates or policies. As Adam Smith wrote over two hundred years ago:

[E]very individual necessarily labours to render the annual revenue of society as great as he can. He generally neither intends to promote the public interest, nor knows how much he is promoting it.... He intends only his own gain, and he is in this, as in many other cases, led by an invisible hand to promote an end which was no part of his intention.

Adam Smith, The Wealth of Nations (ed. Edwinn Canaan, University of Chicago Press, 1976) pp.477. See also, Helen Joyce, "Adam Smith and the Invisible Hand," Math.Plus, at http://plus.maths.org/issue14/features/smith/index.html.

The system in which the invisible hand is most often assumed to work is the free market. Adam Smith assumed that consumers choose for the lowest price, and that entrepreneurs choose for the highest rate of profit. He asserted that by thus making their excess or insufficient demand known through market prices, consumers "directed" entrepreneurs' investment money to the most profitable industry. Remember that this is the industry producing the goods most highly valued by consumers, so in general economic well-being is increased.

${ }^{5}$ See generally, the Competition in Contract Act of 1984 (CICA), Pub. L. No. 98-369, Div. B., Title VII, 98 Stat. 1175 (July 18, 1984); 10 U.S.C. § 2304; 41 U.S.C. § 253. CICA imposed upon the procurement system the now well accepted standard of "full and open competition," which "when used with respect to a contract action, means that all responsible sources are permitted to compete." 48 C.F.R. § 6.003.

Publication pending at 11 Public Procurement Law Review 103 (2002) - Draft Page 3 
marketplace. Accordingly, we promote and sustain contractor participation by instilling integrity and transparency into the system.

By use of the word integrity, we mean to describe rules of conduct for procurement pers onnel in the government and private industry. ${ }^{6}$ Bribery, favouritism, or unethical behaviour have no place in a successful procurement system. ${ }^{7}$ Our regulatory mandate is clear:

Government business shall be conducted in a manner above reproach and ... with complete impartiality and with preferential treatment for none. Transactions relating to the expenditure of public funds require the highest degree of public trust and an impeccable standard of conduct. The general rule is to avoid strictly any conflict of interest or even the appearance of a conflict of interest in Government-contractor relationships. While many Federal laws and regulations place restrictions on the actions of Government personnel, their official conduct must, in addition, be such that they would have no reluctance to make a full public disclosure of their actions. ${ }^{8}$

Our ground rules attempt to ensure fair treatment and ethical behaviour. Private industry expects fair evaluation of its proposals to do contract work. Government agencies expect contractors to

${ }^{6}$ For a more extensive discussion, see generally, Rand Allen, "Integrity: Maintaining a Level Playing Field," in this issue

7 An extensive statutory and regulatory construct is intended to limit both actual and apparent conflicts of interests involving government procurement officials. See 48 C.F.R. § 3.1. See also, generally 18 U.S.C. $\S 201$, discussing gratuities and bribes. It is unlawful to offer, give, solicit or accept gifts (or things of value) to or by government employees. "Gift includes any gratuity, favor, discount, entertainment, hospitality, loan, forbearance, or other item having monetary value." 5 C.F.R. $\S 2635.503$ (emphasis in original). The same regulations define "prohibited source" as "any person who: (2) Does business or seeks to do business with the employee's agency..." 5 C.F.R. $§ 2635.203(d)$ (emphasis added). Although the Office of Government Ethics has promulgated a number of de minimus exceptions, the exceptions are just that - exceptions to the prohibition. See generally, Standards of Ethical Conduct by Employees of the Executive Branch, 5 C.F.R. $\S 2635$; <http://www.usoge.gov/>.

848 C.F.R. $\S 3.101-1$.

Publication pending at 11 Public Procurement Law Review 103 (2002) - Draft Page 4 
compete solely upon the merits of their demonstrated capabilities and the quality and price of their offers, rather than their influence on government officials. This mutual trust, bolstered by meaningful oversight, ${ }^{9}$ not only sustains but enhances the competitive environment.

By system transparency, we mean a system employs procedures by which offerors and contractors (and even the public at large) ensure that government business is conducted in an impartial and open manner. ${ }^{10}$ Professor Sue Arrowsmith suggests that, in a transparent system,

9 The need for oversight of the procurement system implicates issues far broader than minimizing the frequency of collusion or incidence of fraud. This is not to suggest that elimination of fraud and collusion is not important - it is. Rather, it reflects the existence of an over-arching compliance regime, predicated upon an intricate web of statutory and regulatory requirements that define the procurement system. Our rule-bound regime reflects thoroughly western values and judgements regarding ethics, and many nations would argue that we cast our net too broadly in describing corruption. See Kenneth U. Surjadinata, "Comment: Revisiting Corrupt Practices from a Market Perspective”, 12 Emory Int'1 L. Rev. 1021, 1026 (1998) (arguing, inter alia, that developing states see the Foreign Corrupt Practices Act "as a culturally arrogant encroachment on their ability to govern activities exclusively within their borders, in accordance with international law principles on territorial sovereignty."). In procurement, compliance indicates not just high standards of integrity, but also the maintenance of system transparency, the maximization of competition, and the furtherance of a host of Congressionally mandated social policies. Any one of these issues opens to door to a host of pitfalls. For example, integrity in public procurement implicates issues related to, inter alia, personal and organizational conflicts of interest, gratuities, bribes, handling and disclosure of proprietary source selection information, contractor certification of compliance with numerous social programs (such as contractor size status, disclosure of cost or pricing data, or origin of end products delivered), contractor maintenance of a drug-free workplace, contractor allocation fo specified unallowable costs to specific pools, appropriate supervision and cooperation by government employees, proper use by contractors of mandated supplies or raw materials, faithful execution by contractors of inspection and testing provisions, etcetera. Despite the complexity of the Federal procurement system and the reality that this complexity subjects the system to criticism, the statutory and regulatory regime is intended to hold contractors or government personnel accountable for compliance with Congressional mandates.

10 See generally, Sue Arrowsmith, "Towards a Multilateral Agreement on Transparency in Government Procurement”, 47 Int'l \& Comp. L.Q. 793, 796 (1998). In the broader context of transparent government, see the excellent resource, Transparency International, the global coalition against corruption, at http://www.transparency.org/.

Publication pending at 11 Public Procurement Law Review 103 (2002) - Draft Page 5 
the affected parties clearly know both the rules to be applied in conducting procurements as well as information on specific procurement opportunities. ${ }^{11}$ Transparency is maintained in many ways. We publish all of the statutes, regulations, and rules that define our procurement process. ${ }^{12}$ We announce our government's requirements - what we expect to purchase - for all the world to see. ${ }^{13}$ We clearly articulate in every solicitation how offerors will be evaluated. We notify all of the unsuccessful offerors (and members of the public who request the information) which offeror received the award and for what amount. We debrief unsuccessful offerors and explain to them how all of the rules and regulations were followed. ${ }^{14}$ We provide for protest procedures, ${ }^{15}$ where

11 See ibid. Further, Proferssor Arro wsmith explains that transparency:

ensure[s] that procurement decisions are based only on considerations regarde d as 'legitimate' within the system. . . [It also] supports the goals of procurement systems by encouraging and facilitating participation by suppliers. Publicity for procurement opportunities, the application of clear and accessible rules, and the assurance that these rules will be adhered to all mean that suppliers are more willing and able to bid. There is less risk that their participation will prove wasteful....

47 Int'1 \& Comp. L.Q. at 796-97.

${ }^{12}$ For example, visit the GPO Access Site at http://www.access.gpo.gov/su_docs/index.html for all Federal statutes, regulations, and related materials or, more specifically, visit the Federal Acquisition Regulation site at http://www.arnet.gov/far/.

13 The Government publicizes its pending requirements in print and on the Internet through the Commerce Business Daily (CBD). See generally, 48 C.F.R. § 5.101(a)(1); http://cbdnet.gpo.gov.

14 In negotiated government procurements, excluded offerors are entitled to prompt debriefings. 10 U.S.C. § 2305(b)(6)(A); 41 U.S.C. § 253b(f)-(h).

15 The Federal Acquisition Regulation, 48 C.F.R. § 33.101, defines "protest" as: (continued...)

Publication pending at 11 Public Procurement Law Review 103 (2002) - Draft Page 6 
independent third parties and attorneys for the unsuccessful offerors can review all of the agency

records. ${ }^{16}$ We employ appropriate oversight, such as government Inspectors General, ${ }^{17}$ to audit

\section{${ }^{15}$ (...continued)}

a written objection by an interested party to any of the following:

(a) A solicitation or other request by an agency for offers for a contract for the procurement of property or services. (b) The cancellation of the solicitation or other request. (c) An award or proposed award of the contract. (d) A termination or cancellation of an award of the contract, if the written objection contains an allegation that the termination or cancellation is based in whole or in part on improprieties concerning the award of the contract.

${ }^{16}$ Protest procedures can benefit both the parties involved and the procurement system in general.

When the Congress has laid down guidelines to be followed in carrying out its mandate in a specific area, there should be some procedure whereby those who are injured by the arbitrary or capricious action of a governmental agency or official in ignoring those procedures can vindicate their very real interests, while at the same time furthering the public interest....

Scanwell Laboratories v. Shaffer, 424 F.2d 859, 864 (D.C. Cir. 1970), following Judge Frank's analysis in Associated Industries of New York State, Inc. v. Ickes, 134 F.2d 694, 704 (2d Cir.), vacated as moot, 320 U.S. 707 (1943). The court further articulated that: "The public interest in preventing the granting of contracts through arbitrary or capricious action can properly be vindicated through a suit brought by one who suffers injury as a result of the illegal activity, but the suit itself is brought in the public interest by one acting essentially as a "private attorney general." 424 F.2d at 864. The court adopts the "view ... that government officers were making contracts on behalf of the government, that Congress is also a participant in the exercise of the government's proprietary functions, and that the most practicable way to keep the government's contracting officers within their statutory powers is by letting complainants . . . obtain judicial review of the officers' action." 424 F.2d at 866, citing, 3 Kenneth Culp Davis, Administrative Law Treatise 220 (1958). Finally, the court summarized that: "If there is arbitrary or capricious action on the part of any contracting official, who is going to complain about it, if not the party denied a contract as a result of the alleged illegal activity? It seems to us that it will be a very healthy check on governmental action to allow such suits ... as a watchdog of government activity...." 424 F.2d at 866-67.

${ }^{17}$ The Inspectors General are expected, among other things, to (1) conduct and supervise audits and investigations, (2) recommend policies for activities designed to promote economy, (continued...)

Publication pending at 11 Public Procurement Law Review 103 (2002) - Draft Page 7 
agency actions..$^{18}$ Yet it is important to remember that, in the private sector, transparency is rarely considered, let alone valued at a premium. ${ }^{19}$ Accordingly, transparency often proves antithetical to what are perceived as commercial practices. Nonetheless, to the extent that the public's funds are being spent, we believe that maintaining transparency is worthwhile. Further, transparency helps to ensure integrity which, in turn, promotes competition.

Yet, as mentioned above, there is no universal agreement that a procurement system should be premised solely upon transparency, integrity, and competition. Other goals merit discussion.

\section{Competing Aspirations}

One of the most popular aspirations of the 1990's U.S. acquisition reform movement was the concept of efficiency. ${ }^{20}$ Critics of the U.S. system suggest that, historically, efficiency was not a fundamental goal of the procurement process and, arguably, our system is designed to

\footnotetext{
${ }^{17}(\ldots$ continued $)$
}

efficiency, and effectiveness, and (3) prevent and detect fraud and abuse. The Inspector General Act of 1978, 5 U.S.C.A. Appx $\S 2$.

${ }^{18}$ See also the Defence Contract Agency website at http://www.dcaa.mil.

19 "Numerous laws designed to ensure transparency, rationality, and accountability in decision making, including the Administrative Procedure Act (APA) and the Freedom of Information Act, apply to agencies, and not to private actors." Jody Freeman, "The Private Role in Public Governance,” 75 N.Y.U. L. Rev. 543, 586-87 (citations omitted) (2000).

${ }^{20}$ Steven L. Schooner, "Fear of Oversight: The Fundamental Failure Of Businesslike Government," 50 Am. Univ. L. Rev. (forthcoming 2001). 
thwart efficiency. ${ }^{21}$ Yet in any transaction involving commerce, efficiency plays an important role. When we talk about efficiency in this context, we focus primarily upon administrative or transactional efficiency (although the concept could be applied in a far broader context). ${ }^{22}$ In

21 In fact, there is at least one instance where Congress has legislated that administrative efficiency is not an absolute priority. "The reduction of administrative or personnel costs alone shall not be a justification for bundling of contract requirements unless the cost savings are expected to be substantial in relation to the dollar value of the procurement requirements to be consolidated.” 15 U.S.C. $\S 644(\mathrm{e})(2)(\mathrm{C})($ emphasis added).

22

To determine program efficiency, an organization would simply measure the cost per mile swept. But to determine policy efficiency, it would have to measure the cost to achieve a desired level of street cleanliness, by whatev er method - street sweeping, prevention, community self-help. Finally, to measure program effectiveness, a city might measure citizen satisfaction with the level of street cleanliness. But to measure policy effectiveness, it might ask citizens whether they wanted their money spent keeping the streets clean, or whether alternative uses, such as construction or repaving, would be preferable.

David Osborne \& Ted Gaebler, Reinventing Government: How the Entrepreneurial Spirit is Transforming the Public Sector 22 (1992), note 256 at 354 (emphasis in original). See also Herbert A. Simon, Victor A. Thompson \& Donald W. Smithburg, Public Administration 488510 (1991) (discussing the meaning of efficiency and suggesting that the term is vague and ambiguous).

Because of the ethical views that prevail . . , because efficiency is generally regarded as something desirable, the word is a political symbol of considerable potency. It has the power of organizing sentiment behind the proposals to which it is attached. Most people feel they ought to be efficient, and that they ought to want efficient government.

It is not surprising, therefore, that many debates in our political scene about "efficiency" are really debates about what values government should implement.

Ibid. at 510-11 (emphasis in original).

Publication pending at 11 Public Procurement Law Review 103 (2002) - Draft Page 9 
other words, a procurement system is efficient when it spends the least amount of resources in the process of purchasing what is needed. A system that employs the fewest possible people to do the required purchasing consumes less resources. ${ }^{23}$ Specifically, fewer buyers means less money spent on salaries for buyers. If your buyers are overworked, however, such a system becomes more expensive, because your buyers fail to obtain the best prices. ${ }^{24}$ Hence, buyers may

${ }^{23}$ The present political climate in the United States reflects a seemingly mindless obsession with reducing the size of the Federal workforce. See generally, Vice President Al Gore, The Best Kept Secrets in Government: A Report to President Bill Clinton 1, 207 (GPO, 1996) (reflecting that the Executive Branch, excluding the independent Postal Service, has "the smallest workforce in 30 years"). One of the related by-products of this effort is increasing pressure to contract out traditional government services. Without addressing the risks associated with contracting out or privatizing inherently governmental functions, this pressure results in increased costs.

DoD acquisition organizations stated that reductions in in-house . . . support personnel required the[m] to contract for additional services, such as engineering and logistical analysis, that the Government once would have provided. As a result, technical support costs increased because ... obtaining contract support was more expensive than obtaining in-house ... support. ... [C]ontract labor rates are significantly higher [ $\$ 20,000$ to $\$ 180,000]$ per staff year than rates ... charged for the same service performed by Government employees.

Inspector General Report, Acquisition Workforce, supra note 69 at 18. See also Richard Stillman II, The American Bureaucracy: The Core of Modern Governement, 307-309 (2d ed. 1996) (suggesting that the growth of contracting out has "tended to be discussed elsewhere, the procurement workforce has borne the brunt of the downsizing frenzy. Congress incrementally mandated a 55 percent reduction of the Federal acquisition workforce between 1989 and 2001. See generally, the National Defense Authorization Act for 2000, Pub. L. No. 106-65, § 922, 113 Stat. 512, 724 (October 5, 1999).

${ }^{24}$ Office of the Inspector General, Department of Defense, DOD Acquisition Workforce Reduction Trends and Impacts, Report d-2000-088 (February 29, 2000) (visited August 1, 2000) $<$ http://dodig.osd.mil/audit/reports/00-088.pdf $>$. This study identified, among many others, the following effects of the personnel reductions: (1) increased backlog in closing out completed contracts; (2) insufficient staff to manage requirements; (3) reduced scrutiny and timeliness in (continued...)

Publication pending at 11 Public Procurement Law Review 103 (2002) - Draft Page 10 
pay too much for what they buy.

We also have increased our emphasis upon the concept of best value ${ }^{25}$, or what some call value for money. ${ }^{26}$ In other words, we aspire to focus upon getting the best deal - or the best bargain - for the public's money. Such an emphasis seems logical. Unfortunately, the pursuit of best value typically requires greater buyer resources, from market research to negotiation. Similarly, obtaining best value may not always please the customer (for example, if the customer requires premium quality regardless of price).

Also, in the 1990's, the U.S. procurement system increased its emphasis on obtaining customer satisfaction for end users. It makes sense for buyers to try to please those for whom they serve. Unfortunately, pleasing end users, especially if the end user favours specific suppliers or demands that goods be provided quickly, frequently results in less competition and higher prices, ${ }^{27}$ or simply embarrassing policy decisions.

${ }^{24}$ (...continued)

reviewing acquisition actions; (4) difficulties retaining personnel; and (5) insufficient contract surveillance. Ibid. at 17-20.

25 "'Best value' means the expected outcome of an acquisition that, in the Government's estimation, provides the greatest overall benefit in response to the requirement." 48 C.F.R. $\S 2.101$.

${ }^{26}$ For example, see the vision statement of the United Kingdom's Office of Commerce: "To work with civil government as a catalyst to achieving best value for money in commercial activities." http://www.ogc.gov.uk/ogc/isite.nsf/index.html.

${ }^{27}$ Focus on customer satisfaction may cause buyers to "place inordinate weight on product quality[,]" skewing the expected price-quality tradeoffs. William Kovacic, "Procurement Reform and the Choice of Forum in Bid Protest Disputes," 9 Admin. L.J. Am. U. 461, note 33 at 486-87 (1995), citing Robert C. Marshall, Michael J. Muerer, \& Jean-Francois Richard, "The Private Attorney General Meets Public Contract Law: Procurement Oversight by Protest,” 20 Hofstra L. Rev. 1, note 160 at 7-8 (1991).

Publication pending at 11 Public Procurement Law Review 103 (2002) - Draft Page 11 
Historically, our elected representatives have viewed our procurement system as a vehicle to distribute wealth. ${ }^{28}$ For example, our government has chosen to leverage its purchases to support domestic firms and, more specifically, small businesses. ${ }^{29}$ At the same time, our

${ }^{28}$ The author does not believe that wealth distribution is one of the procurement system's primary goals. This does not suggest that the Congress does not use the procurement system to attempt to redistribute wealth. But those efforts are transitory for the same reasons they are controversial. Two examples demonstrate the never-ending turbulence affecting social policies. First, in the same year that Congress increased the government-wide goal for small business participation in federal procurement from 20 to 23 percent, it extended the Small Business Competitiveness Demonstration (Comp-Demo) Program. The Comp-Demo favors big businesses by stopping agencies from setting aside contracts for small business in four selected industries in which small businesses have proven themselves competitive. Second, Congress effectively gutted its affirmative action contracting program by mandating that the Defense Department (representing 60 percent of government buying) suspend use of price preferences for disadvantaged firms following any year in which the five-percent participation goal is met. See Steven L. Schooner, "Mixed Messages: Heightened Complexity In Social Policies Favoring Small Business Interests”, 8 P.P.L.R. CS78, CS82-83 (No. 3, 1999). Moreover, wealth distribution is merely a subset of the larger phenomenon of burdening the procurement process (or, for that matter, the process of governing) with efforts to promote social policies. These social policies, in addition to those that potentially distribute wealth to domestic manufacturers, essential military suppliers, and small (and small disadvantaged and women-owned) businesses, also mandate drug-free workplaces, occupational safety standards, compliance with labor laws, preferences for environmentally friendly purchasing practices, etcetera. Accordingly, while the author concedes that Congressional manipulation of the procurement process is a significant aspect or feature of the system, the author cannot agree that wealth distribution is a fundamental purpose of the procurement regime.

29 For a taste of the ever-evolving mandates that burden the U.S. procurement process., see 48 C.F.R. Part 19 (Small Business Programs, including preferences for disadvantaged businesses and women-owned businesses), Part 22 (Application of Labor Laws to Government Acquisitions), Part 23 (Environment, Conservation, Occupational Safety, and Drug-Free Workplace), Part 25 (Foreign Acquisitions (or domestic preferences)); 48 C.F.R. Subpart 26.1 (Indian Incentive Program), Subpart 26.3 (Historically Black Colleges and Universities and Minority Institutions). See, also, the recent Federal Acquisition Regulation amendments implementing Executive Order 13101, at 65 Fed. Reg. 36016 (June 6, 2000), amending 48 C.F.R. $\S \S 4.3,11.0,11.3,23.4,23.7$ (including affirmative programs to procure environmentally preferable products or services, such as products or services "that have a lesser or reduced effect on human health and the environment when compared with competing products or services that serve the same purpose" and mandating the use of paper with a minimum recycled content, 
procurement dollars may be directed towards specific manufacturers to maintain sufficient expertise or industrial base capacity in anticipation of future contingencies. You may target your buying towards contractors located in geographical areas of high unemployment. It is axiomatic that government spending can influence behaviour and infuse growth in communities and economic sectors. Conversely, efforts to redistribute wealth through the procurement system by their very nature - restrict competition. ${ }^{30}$ Quite simply, as various constituencies or special interest groups compete for their perceived "fair share of the pie," others are left wanting.

It is difficult to describe a procurement regime without acknowledging the role of risk avoidance. Avoiding undue risk is a fundamental responsibility of any governing body. Conversely, improper obsession with risk avoidance can suffocate creativity, stifle innovation and render and institution ineffective. Further, there are infinite mechanisms available to control different types of risk. For example, in the United States, the concept of responsibility is used to filter out undesirable or incompetent contractors. ${ }^{31}$ The manner in which the government's needs

\footnotetext{
${ }^{29}($...continued $)$ etcetera.).

${ }^{30}$ Moreover, the controversial nature of these policies often lead to strong incentives to avoid them. See generally, Mark Cancian, "Acquisition Reform: It's Not as Easy as it Seems", Acquisition Rev. Q. 189, 191 (Summer 1995), clarifying that:
}

These goals are often regarded as illegitimate by people inside the system because they have no direct bearing on national security or on acquisition. Indeed, they look like the workings of powerful special interests trying to bend society's rules in their favor. However, democracy is a messy form of government. One pers on's selfish special interest is another's vital national priority.

31 To be determined responsible, a contractor must have adequate financial resources; be able to comply with the required schedule; have a satisfactory performance record; have a (continued...) 
are described - for example, whether design or performance specifications are utilized - can shift performance risks between contracting parties. ${ }^{32}$ Different types of contracts - ranging from firm fixed price to cost reimbursement vehicles - modulate the government's exposure to potential cost overruns..$^{33}$ In addition, the termination for convenience clause permits the government to avoid performance where its need for the contracted items has evaporated or been overtaken by events. $^{34}$

Finally, another valuable systemic goal is frequently lost in efforts to achieve some or all of the previously discussed policies. Nonetheless, the importance of uniformity, particularly in maximizing transparency, competition, and efficiency, among others, cannot be overstated. A uniform procurement system suggests that all government instrumentalities buy the same way, following the same laws, rules, and practices. Such a system is efficient because sellers do not need to learn new rules in order to do business with different agencies or departments. Further, it is much easier to train all of the government's buyers, and it permits buyers greater flexibility to work for various agencies or departments during their careers. In addition, if the government

${ }^{31}$ (...continued)

satisfactory record of integrity and business ethics; have the necessary organization, experience, accounting and operational controls, and technical skills; have the necessary production, equipment and facilities; and be otherwise qualified and eligible under applicable laws and regulations. 48 C.F.R. $\S 9.104-1$.

32 See 48 C.F.R. $\S 11.002(a)(2)$.

33 See generally 48 C.F.R. Part 16.

34 See generally 48 C.F.R. Part 49; 48 C.F.R. $\S \S 52.249-1,-2$.

Publication pending at 11 Public Procurement Law Review 103 (2002) - Draft Page 14 
consistently uses standard provisions and clauses, ${ }^{35}$ the process operates more smoothly. ${ }^{36}$

Transactions become more routine. All parties to the transaction understand the rules to the game.

\section{Conclusion}

Ultimately, each government must decide how much discretion or flexibility it wishes to delegate to its buyers. ${ }^{37}$ For each individual transaction, greater buyer flexibility should result in higher customer satis faction and better value for money. For all of your trans actions, taking a

35 For an informative table identifying all of the required or optional government-wide provisions and clauses, organized by the numerous contract types utilized by the government (for example, fixed-price supply, cost-reimbursement supply, fixed-price research and development, cost-reimbursement construction, time and materials, commercial item, etcetera.), see the provision and clause matrix at 48 C.F.R. $\S 52.301$.

36 Steven L. Schooner, "Fear of Oversight: The Fundamental Failure Of Businesslike Government," 50 Am. Univ. L. Rev. pp. 94-95.

37 For example, the author is concerned that the U.S. reforms of the 1990 provided buyers discretion to act in a businesslike fashion at the expense of oversight and bureaucratic control. In this regard, readers may find Malcolm Sparrow informative:

The nature and quality of regulatory practice hinges on which laws regulators choose to enforce, and when; on how they focus their efforts and structure their uses of discretion; on their choice of methods for procuring compliance. Yet the vogue prescriptions for the reinvention or reform of government . . say little about these issues and sometimes ignore them altogether. The popular prescriptions for reform focus on service, customers, quality, and process management, not on compliance management, risk control, or structuring the application of enforcement discretion. They rely heavily on management tools and methods imported from the private sector, which has few comparable challenges.

Malcolm K. Sparrow, The Regulatory Craft: Controlling Risks, Solving Problems, and Managing Compliance 2 (2000) (emphasis added).

Publication pending at 11 Public Procurement Law Review 103 (2002) - Draft Page 15 
systemic view, broad delegations of discretion or flexibility may reduce transparency and competition. Accordingly, this discretion may entail a lack of control that may threaten public confidence in your procurement system.

No system can achieve all of these goals. Norcan a state expect that its objectives for its system will remain constant over time. Determining which goals are most important is a daunting, ever-evolving challenge.

Because no system can achieve all of the goals here (or the many not discussed), your desiderata entails important tradeoffs. There are significant transactional, economic, and social costs associated with maximizing transparency, integrity, and competition. Nonetheless, the author believes these costs are an excellent long-term investment.

Publication pending at 11 Public Procurement Law Review 103 (2002) - Draft Page 16 